\title{
The Prediction of Soil Bearing Capacity Using Error Root Mean Square
}

\author{
$1^{\text {st }}$ Ridayati $^{1}, 2^{\text {nd }}$ Anggi Hermawan ${ }^{2}$
}

Teknik Sipil ITNY

\begin{abstract}
Good Slope construction is strongly influenced by good foundations. Good foundation planning is required to test soil investigations on the land to be erected. The purpose of this study was to test the behavior of soil in the river gadjah wong Yogyakarta. The data is processed by simple linear regression to determine the relationship between the depth of soil and the bearing capacity of soil. Root mean square error is used to predict bearing capacity of subsurface soil. In the test it is known that the depth of the soil affects the size of the cone resistant. There is a relationship between the depth of the soil and the friction sleeve too. The safest foundation is a wells foundation on diameter $0.8 \mathrm{~m}$ with an ERMS value of 1.889701 .
\end{abstract}

Keywords: Bearing capacity, foundation, ERMS

\section{Introduction}

Flood is a characteristic that can change and damage the initial treatment or bottom of the river and surrounding area of the river. According to Government Regulation No. 38/2011, rivers are natural and / or artificial waterways or containers in the form of water flowing networks and water in them, starting from upstream to downstream, with boundary right and left by border lines. In general, the problems are same in every river of Yogyakarta, that is illegal settlements. It lies narrow river bodies. The risk of disasters such as floods, landslides, cold lava eruption of Merapi, garbage, and industrial waste [5].

The Soil is formed from soil grains of variety sizes [1]. According to [3],[4], Soil texture shows the roughness. Soil Investigation test is needed to determine the bearing capacity and characteristics of soil and geological conditions. This test can also determine the density and bearing capacity of soil and the nature of soil corrosivity, the type of foundation. It means that the bearing capacity can support the construction. The results of this soil investigation determine an alternative / type of depth and foundation dimensions which are the most economical but still safe.

Knowing the bearing capacity of the soil can plan a structure that is sturdy and earthquake resistant which will ultimately provide a sense of comfort and security. Soil investigations carried out in the field using Sondir (DCP), Boring Test, Penetration Test (SPT) and others.

Based on the above background, the author is interested in studying soil behavior on Gadjah Wong river bank with simple linear regression using Error Root Mean Square to predict the bearing capacity of subsurface soils. 


\section{Research Methods}

The data needed secondary and primary data. The data collection techniques used documentation, literature studies and field observations. Secondary data related agency reports and literature studies on the structure of the soil layer and its relationship to the depth of the soil. Primary data is a general description of field conditions [2],[6],[7],[8].

The Analyzed data included the behavior of clay in the Gajah Wong river bank, then determined the depth of the safe foundation base. The data is processed by simple linear regression to find out the relationship between the depth of soil with the bearing capacity of soil. By using the root mean square error can be predicted the bearing capacity of subsurface soil.

\section{Results And Discussion}

In general, the land around Gajah Wong River is eroded by flooding from the river. There is no material access road at the project site, so the road must be made. In addition there are the wastes of processing "tahu / tempe" industry dumped in the river and polluted the river environment.

The author collaborates with a consultant to work together to determine the condition and nature of subsurface soils. It will be used for analysis the type and depth of the foundation and bearing capacity of the soil. The soil investigation is a static penetration test.

\section{Static Penetration Test}

Two static penetration test points named S1 and S2 (Sondering) with 2 ton capacity to measure the pressure of the sondir when the conus sondir penetrates the soil layer. It will be known that changes in density and friction sleeve resistance of soil layers. Sondering is carried out until the depth of the hard layer. It is done until the sondir value exceeded $200 \mathrm{~kg} / \mathrm{cm} 2$ or the depth of 20 meters if no hard soil layer is found.

Sondering S1 is carried out to a depth of $4.6 \mathrm{~m}$ with a sondir value $225 \mathrm{~kg} / \mathrm{cm} 2$. Sondiring $\mathrm{S} 2$ is carried out to a depth of $7.8 \mathrm{~m}$ with a sondir value $225 \mathrm{~kg} / \mathrm{cm} 2$. The relationship between the depth and strength of the land on the Gajah Wong river bank is shown on the graph below. 


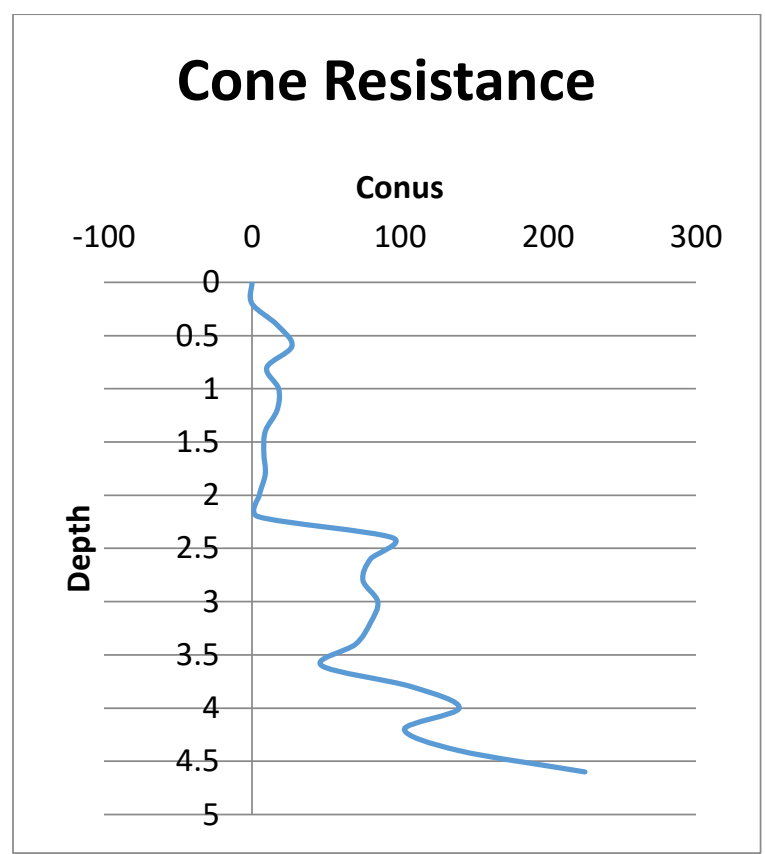

Fig. 1. Graph of cone Resistance S1

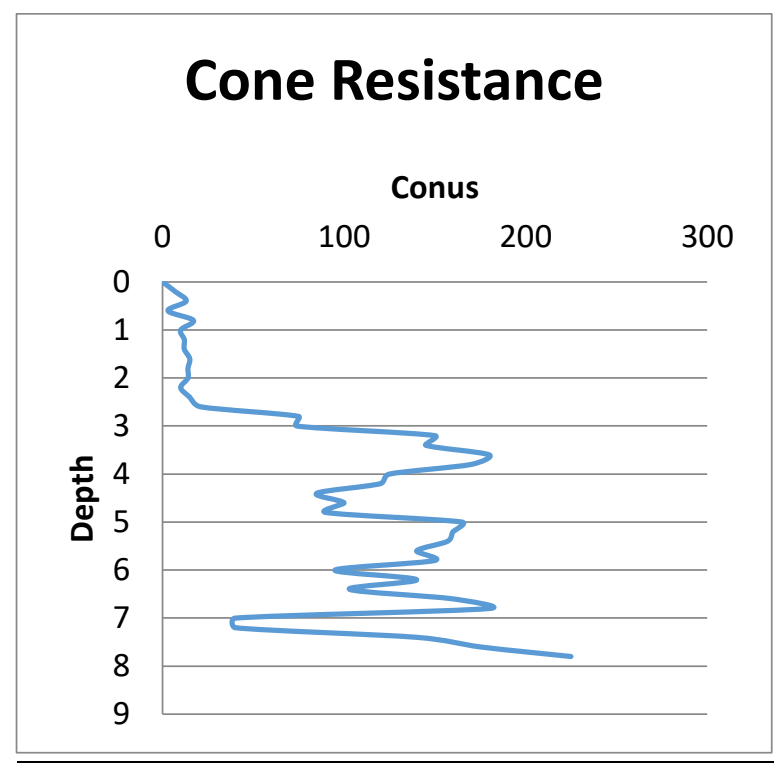

Fig. 2. Graph of cone Resistance S2 


\section{The Relationship between Soil Depth and Bearing Capacity}

The relationship between soil depth and bearing capacity is calculated by simple linear regression. It determined the relationship between soil depth and cone resistant, between soil dept and friction sleeve.

From Data S1 and S2, It takes the dependent variable y is cone resistant $(\mathrm{Cr})$ and the independent variable $\mathrm{x}$ is depth (dept).

Table 1. The Output of relationship between soil depth and cone resistant S1

Model Summary ${ }^{b}$

\begin{tabular}{|l|l|l|l|l|}
\hline Model & $R$ & $R$ Square & $\begin{array}{l}\text { Adjusted } \\
\text { Square }\end{array}$ & $\begin{array}{l}\text { Std. Error of the } \\
\text { Estimate }\end{array}$ \\
\hline 1 & $.844^{\mathrm{a}}$ & .712 & .699 & 31.85378 \\
\hline
\end{tabular}

a. Predictors: (Constant), kedalaman

b. Dependent Variable: Conus

\section{Coefficients $^{\mathrm{a}}$}

\begin{tabular}{|cc|l|l|l|l|l|}
\hline \multicolumn{2}{|l|}{ Model } & \multicolumn{2}{|l|}{ Unstandardized Coefficients } & $\begin{array}{l}\text { Standardized } \\
\text { Coefficients }\end{array}$ & \multirow{2}{*}{ Sig. } \\
\cline { 3 - 5 } & & B & Std. Error & Beta & & \\
\hline \multirow{2}{*}{1} & \begin{tabular}{l} 
(Constant) \\
\cline { 3 - 5 }
\end{tabular} & -22.453 & 12.608 & & -1.781 & .089 \\
& kedalaman & 34.617 & 4.697 & .844 & 7.371 & .000 \\
\hline
\end{tabular}

a. Dependent Variable: Conus

In S1, there is a relationship between soil depth and cone resistant on Gajah Wong river bank with a regression value of $y=-22,453+34,617 \mathrm{x}$. It means that an increase in depth of 1 meter will increase cone resistant amounting to $34,617 \mathrm{~kg} / \mathrm{cm} 2$. The magnitude of the effect of depth on cone resistant amounting to $71.2 \%$ and $28.8 \%$ was influenced by other factors.

Table 2. The Output of relationship between soil depth and cone resistant S2

Model Summary

\begin{tabular}{|l|l|l|l|l|}
\hline Model & $\mathrm{R}$ & R Square & $\begin{array}{l}\text { Adjusted } \\
\text { Square }\end{array}$ & $\begin{array}{l}\text { Std. Error of the } \\
\text { Estimate }\end{array}$ \\
\hline 1 & $.745^{\mathrm{a}}$ & .555 & .543 & 45.89725 \\
\hline
\end{tabular}

a. Predictors: (Constant), kedalaman

b. Dependent Variable: Conus

\section{Coefficients $^{\mathrm{a}}$}




\begin{tabular}{|ll|l|l|l|l|l|}
\hline \multicolumn{2}{|l|}{ Model } & \multicolumn{2}{|l|}{ Unstandardized Coefficients } & $\begin{array}{l}\text { Standardized } \\
\text { Coefficients }\end{array}$ & $\mathrm{t}$ & \multirow{2}{*}{ Sig. } \\
\cline { 3 - 5 } & $\mathrm{B}$ & Std. Error & Beta & & \\
\hline \multirow{2}{*}{1} & (Constant) & 4.278 & 14.246 & & .300 & .766 \\
& kedalaman & 21.640 & 3.143 & .745 & 6.884 & .000 \\
\hline
\end{tabular}

a. Dependent Variable: Conus

In $\mathrm{S} 2$, there is a relationship between soil depth and cone resistant on Gajah Wong river bank with a regression value of $y=4,278+21,640 x$. The magnitude of the effect of depth on cone resistant amounting to $55.5 \%$.

\subsection{The Relationship between Soil Depth and Friction Sleeve}

From data S1 and S2 with the dependent variable y is friction sleeve (fr) and the independent variable $\mathrm{x}$ is depth (dept).

Table 3. The Output of relationship between soil depth and friction sleeve S1

Model Summary ${ }^{b}$

\begin{tabular}{|l|l|l|l|l|}
\hline Model & $\mathrm{R}$ & R Square & $\begin{array}{l}\text { Adjusted } \\
\text { Square }\end{array}$ & $\begin{array}{l}\text { Std. Error of the } \\
\text { Estimate }\end{array}$ \\
\hline 1 & $.588^{\mathrm{a}}$ & .346 & .317 & 1.96929 \\
\hline
\end{tabular}

a. Predictors: (Constant), depth

b. Dependent Variable: friksion

Coefficients $^{\mathbf{a}}$

\begin{tabular}{|ll|l|l|l|l|l|}
\hline \multirow{2}{*}{ Model } & \multicolumn{2}{|l|}{ Unstandardized Coefficients } & $\begin{array}{l}\text { Standardized } \\
\text { Coefficients }\end{array}$ & $\mathrm{t}$ & \multirow{2}{*}{ Sig. } \\
\cline { 3 - 6 } & $\mathrm{B}$ & Std. Error & Beta & & \\
\hline \multirow{2}{*}{1} & (Constant) & 1.457 & .783 & & 1.861 & .076 \\
& depth & 1.001 & .293 & .588 & 3.413 & .002 \\
\hline
\end{tabular}

a. Dependent Variable: friksion

In $\mathrm{S} 1$, it is known that there is a relationship between the depth of the soil and friction sleeve. The regression formula is $y=1,457+1,001 x$. It means that an increase in depth of 1 meter will increase friction sleeve by 1,001 . The magnitude of the effect of depth on friction sleeve was $34.6 \%$ while $65.4 \%$ was influenced by other factors 
Table 4. The Output of relationship between soil depth and friction sleeve S2

Model Summary ${ }^{b}$

\begin{tabular}{|l|l|l|lr|l|}
\hline Model & $\mathrm{R}$ & R Square & $\begin{array}{l}\text { Adjusted } \\
\text { Square }\end{array}$ & $\begin{array}{l}\text { Std. Error of the } \\
\text { Estimate }\end{array}$ \\
\hline 1 & $.704^{\mathrm{a}}$ & .495 & .482 & 2.07376 \\
\hline
\end{tabular}

a. Predictors: (Constant), kedalaman S2

b. Dependent Variable: hamb lekat S2

\section{Coefficients $^{\mathrm{a}}$}

\begin{tabular}{|ll|l|l|l|l|l|}
\hline \multirow{2}{*}{ Model } & \multicolumn{2}{|l|}{ Unstandardized Coefficients } & $\begin{array}{l}\text { Standardized } \\
\text { Coefficients }\end{array}$ & t & \multirow{2}{*}{ Sig. } \\
\cline { 3 - 5 } & & B & Std. Error & Beta & & \\
\hline \multirow{2}{*}{1} & \begin{tabular}{l} 
(Constant) \\
\cline { 3 - 6 }
\end{tabular} & 1.443 & .644 & & 2.241 & .031 \\
& kedalaman S2 & .867 & .142 & .704 & 6.106 & .000 \\
\hline
\end{tabular}

a. Dependent Variable: hamb lekat S2

In S2, there is a relationship between the depth of the soil and friction sleeve. The regression formula is $y=1,443+0,867 x$. The magnitude of the effect of depth on friction sleeve amounting to $49.5 \%$.

The prediction of soil bearing capacity

The prediction of soil bearing capacity will be calculated by error root mean square error (RMSE)

Explanation:

$$
R M S E=\sqrt{\frac{\sum_{i=1}^{24}\left(y-y^{\prime}\right)^{2}}{n}}
$$

$\mathrm{y}=$ initial data (actual data)

$y^{\prime}=$ final data (estimated data)

$\mathrm{n}=$ the amount of $\mathrm{y}^{\prime}$, it is obtained from the regression equation $\mathrm{y}=1,457+1,001 \mathrm{x}$ by entering $\mathrm{x}$ as a depth into the friction sleeve equation $y$.

In S1, $y=1,457+1,001 x$ is obtained that the root mean square error value is 1.889701

In S1, $y=1,443+0,867 x$ is obtained that the root mean square error value is 2,021253 .

Thus, it can be concluded that soil depth significantly influences bearing capacity is correct.

\section{CONCLUSION}

The land around Gajah Wong River is eroded by flooding from the river. In addition, there are the wastes of processing "tahu / tempe" industry dumped in the river and polluted the river environment. 
Two static penetration test points (Sondering) namely S1, S2 with 2 ton capacity sondir to measure the value of sondir when the conus sondir penetrates the soil layer. Sondering S1 is carried out to a depth of $4.6 \mathrm{~m}$. Sondiring S2 is carried out to a depth of 7.8. It was able to carry the burden of the plan and a type of wells was used.

The results of the test are the depth of the soil affects the amount of cone resistant with regression value $y=1,457+1,001 x$. The soil depth affects the size of the friction sleeve with regression value $y=1,443+0,867 x$.

The prediction of soil bearing capacity is calculated by error root mean square it is obtained that the ERMS value is 1.889701 on S1 and 2,021253 On S2. It means that the soil depth correctly influences the bearing capacity

\section{Reference}

[1] Bowles, E Yoseph, Engineering Properties of Soils and Their Measurement. Mc Grow-Hill, Inc, 1970.

[2] Ghozali, Imam, Aplikasi Analisis multivariate dengan program SPSS, Semarang, Penerbit UNDIP, 2001.

[3] Hardjowigeno, S, Ilmu Tanah, Mediyatama Sarana Perkasa, Jakarta, 1992.

[4] Hardiyatmo, H, Teknik Pondasi 1, FT UGM, Yogyakarta, 2002.

[5] Hasnawir, Ambang Batas Curah Hujan di Kaldera Bawakaraeng, Sulawesi Selatan, Jurnal Penanggulangan Bencana Volume 3 Nomor 1, 2012, hal 14-24.

[6] Pangesti, Sri, Zulaela, Gunardi, Abdurakhman, Herni Utami, Metode Statistika, FMIPA UGM, Yogyakarta, 2004.

[7] Supriharyono, Intisari Materi Kuliah metodologi Penelitian, Program Pasca Sarjana Magister Teknik Sipil Universitas Diponegoro, Semarang, 2002.

[8] Zulaela, Analisis Regresi Terapan, Laboratorium Komputasi Matematika dan Statistika FMIPA UGM, Yogyakarta, 2008. 